\title{
On representation and speculation: a case for the use of representational practices in Sci- Art
}

In 'Speculative listening', Kaya Barry, Michele Lobo and Michelle Duffy (2021) provide a thought-provoking exploration into how art-science practice might facilitate a deeper societal engagement with the realities of climate change. What is needed to 'shift the global discourse on environmental change', they suggest, is not yet more representations (descriptions, images, photos, graphs, data tables and so on) but a 'more-thanrepresentational' approach. They argue that it is through forms of play and experiment that emphasise not distanced observation and measurement but immersion and flow, embodiment and movement, affect and sensation' that people may become attentive to 'the "mattering" done by other things'. They illustrate this argument through a discussion of two artworks concerning sea-ice: a video that uses satellite imagery and other data to compress slow, planetary-scale changes in sea-ice coverage into human perceptual time, and a sound composition using treated recordings of the subsonic sounds made as a moving iceberg interacts with the surrounding sea water and the sea floor.

I agree that we need more imaginative ways to present and engage with climate data, and welcome such experiments. However, I want to stage a defence of representation as a resource for experimental and speculative practice. Indeed, close attention to Barry, Lobo and Duffy's examples suggest that the way that these two artworks work actually relies on the capacity of representational signification to open up a 'play' between world and meaning.

What do I mean by the representational? Fundamentally, representation is a relation where a 'this' stands for a 'that' for a 'something else'. In the semiotics of C. S. Peirce, all signs can be said to be representational. Different signs 'stand in' using different logics: Peirce famously distinguishes icons (resemblance), indices (causation) and symbols (convention). But fundamental to all processes of signification is representation, understood in a broad sense as a relation that Peirce calls 'thirdness', because it involves three key elements: a sign or 'representamen' that represents an object to an interpretant (for a summary, see Peirce 1868).

Proponents of non-representational theory such as Nigel Thrift (2008) and Hayden Lorimer (2005) argue that the dominant emphasis in the social sciences on meaning as representation (shared by positivists and social constructionists alike) misrepresents both the world and our placement in it - a world characterised by flow and flux and a lack of clear boundaries. 'Re-present', after all, means literally 'to place before' an observer, suggesting a separation of subject and object. To use Peirce's (shifting) terminology, emphasising the non-representational is to pay more attention to the monadic firstness of what Peirce calls the qualisign - the immediacy of how things feel - or to the dyadic secondness of the sinsign - how we react to the brute facticity of things. Compared to methodological orthodoxy, this expanding of attention to other modes of meaning can certainly be called experimental - experimentation being the fifth of Thrift's seven principles of nonrepresentational theory (2008: 12). 
I feel very at home with the capaciousness of non-representational theory as it has been developed in the social sciences - its openness to the animacy of the non-human world and its welcoming of diverse epistemologies. However, it strikes me that what Thrift, Lorimer et al. are really reacting against is the dominance of certain kinds of representation, rather than representation in itself. But furthermore, I want to develop the thought that the loss of total immersion in the flux and becoming of the world that the representational represents is also a gain - one that is part of the precondition of experimentation. To put it in Peirce's terminology, perhaps the thirdness of the representational legisign is the more natural home of speculation and experiment as both possibility and right.

One way to follow this thought is to see the possibility of speculation as inherent in language from its inception - as inseparable from the act of description or representation. Jacques Derrida argued as much in On Grammatology: 'Within the voice, the presence of the object already disappears. ... [There is] a sort of fiction, if not a lie, at the very origin of speech. Speech never gives the thing itself, but a simulacrum that touches us more profoundly than the truth, "strikes" us more effectively' (1976: 240). The origin of language sunders the world in a way that creates the possibility of truth, but also of falsity - and also of modes of signification that play with the relation between the two. Elsewhere, Derrida puts it like this: 'the possibility of fiction and lie, simulacrum and literature, that of the right to literature insinuates itself, at the very origin of truthful testimony, autobiography in good faith, sincere confession, as their essential compossibility' (Derrida 2000: 42).

If the right to literature, to fabulation and fiction, is inherent in language, reference and representation, so too is the right to speculation. And we can put a history to the articulation and enactment of this right - at least as it evolved in the West. In the classical and medieval eras the dominant understanding of language was conjunctive in nature, with no clear distinction between the world of thoughts and words and the world of things (Reiss 1982: 59). Language was seen as a web of sympathies amongst words and things, allowing magical forms of action on the basis of principles of similitude, analogy and empathy (Foucault 1970).

However, in the early modern period a disjunctive idea of language as referential became dominant. The sundering of word and thing, and then the fixing of their relation in a specific model of representation (the dominance of which is the main target of the nonrepresentational theorists), was a crucial element in the emergence of modern science (Vickers 1984). But the separation of word and thing was no less implicated in the rise of the modern imagination. It is no accident that the early modern period also saw a flowering of speculation and play, of Renaissance-humanist representational experimentation before the seventeenth-century saw the rise of a rationalist and dogmatic style in natural philosophy that pursued a singular truth established on certain foundations (Toulmin 1992).

An analogy with representation in politics might help here. Frank Ankersmit argues for an aesthetic understanding of political representation. Just as the artist's creativity 'has its natural and exclusive locus in the gap between art and reality, representation and represented', so too he argues that the task of the elected politician is not to reproduce perfectly the opinions of those that elected them, but to work creatively within the gap 
between represented and representative (Ankersmit 2002: 36). 'Without representation,' he argues, 'there is no represented - and without political representation, there is no nation as a truly political entity. ... Political reality comes into being only when the nation has understood itself as a represented' (ibid.). By analogy, without representation in Peirce's broadest sense - without the play between object and meaning - perhaps there is no environment, and nothing living in it.

Representation can seem a very human practice - and as we have seen in the narrow sense it is one that has an affinity with Western and particularly modern thought. And of course the particular representations of climate change that we use, and how we use them, should be subjected to critique. But more fundamentally the human act of representation can be seen as itself the mobilisation of a more-than-human planetary power, an aspect of planetary multiplicity, whereby the substance of the world is folded and made more complicated (Clark and Szerszynski 2021: 88). In neocybernetic thought, life originates with a folding of matter, form and process through which an organism creates a new kind of relation between inside and outside, one of dependent independence. The folding creates a dependency on continued metabolic flows, but also a freedom, since the living organism is not merely compelled by efficient causes originating in its environment, but experiences and reacts to its milieu as it experiences it (Clarke 2020). It is a mistake to think that the folds of signification are mere obfuscation, a barrier to experiencing the world itself; it is folding that creates a world and its inhabitants.

Similarly, it is striking that the examples used in 'Speculative listening' are not only filled with representations - satellite images, numbers, dates, aural recordings - but ones which have gone through a more-than-usual series of transductions, transformations and juxtapositions before being re-presented. In both pieces, the visceral experience of hearing or seeing is combined with a complex layering of what we might call 'thirdly' representational practices, in which one thing stands for another to a third, creating a web of playful gaps within which both artist and audience can experiment and speculate - and can also reflect on the representational choices and practices that have shaped their experience.

Thus, in the time-lapse video, it is exactly through the reflexive composition of representations that we are able to "search for, to listen to, the changes that are happening at a scale that exceeds our individual human form". Similarly it is the clever way that Andreas Blick's sonic composition frost pattern is crafted that creates a perceptual space for us to adopt 'an ethos of attentiveness, curiosity and openness to engage with these distant worlds'. It is true that 'the sounds and images emerge as active facilitators of thinking, feeling, and listening differently to the data' - but it is arguably not so much conjunctive non-representational immersion but disjunctive representational modes that create the space for speculation.

'To explain' something literally means 'to flatten out', to make something plain and clear to the mind; scientific modes of description and explanation all-too often adopt this reductive mode. But the folds are what make the world a world, so that to 'explain' a complicated thing too robustly is to destroy what is being explained. The two art works discussed work 
not by removing folds, but by adding new ones. To move from being an unbounded part of the world, to hearing the world, to listening to the world, to representing the world, to reflecting on those representations, and so on - with each of these moves, more and more layers are added to the folding of the world, making it not poorer but richer. To reference the ' $p l i$ ' of the Latin verb plicare, 'to fold', that is embedded in words such as 'multiplicity' and 'complicated', I would make a plea for the pli that brings play.

\section{References}

Ankersmit, FR (2002) Political Representation, Stanford, CA: Stanford University Press. Barry, K, Lobo, M and Duffy, M (2021) 'Speculative listening: melting sea ice and new methods of listening with the planet,' Global Discourse.

Clark, N and Szerszynski, B (2021) Planetary Social Thought: The Anthropocene Challenge to the Social Sciences, Cambridge: Polity.

Clarke, B (2020) Gaian Systems: Lynn Margulis, Neocybernetics, and the End of the Anthropocene, Minneapolis: University of Minnesota Press.

Derrida, J (1976) Of Grammatology, tr. Spivak, GC, Baltimore: John Hopkins University Press.

Derrida, J (2000) 'Demeure: fiction and testimony,' in The Instant of my Death / Demeure: Fiction and Testimony, Blanchot, $\mathrm{M}$ and Derrida, J, tr. Rottenberg, E, Stanford, CA: Stanford University Press, pp. 13-103.

Foucault, M (1970) The Order of Things: An Archaeology of the Human Sciences, London: Tavistock.

Lorimer, H (2005) 'Cultural geography: the busyness of being 'more-than-representational', Progress in Human Geography, 29(1), pp. 83-94.

Peirce, CS (1868) 'On a new list of categories,' Proceedings of the American Academy of Arts and Sciences, 7, pp. 287-98.

Reiss, TJ (1982) The Discourse of Modernism, Ithaca, New York: Cornell University Press.

Thrift, N (2008) Non-Representational Theory: Space, Politics, Affect, London: Routledge.

Toulmin, S (1992) Cosmopolis: The Hidden Agenda of Modernity, Chicago, IL: University of Chicago Press.

Vickers, B (1984) 'Analogy versus identity: the rejection of occult symbolism, 1580-1680,' in Occult and Scientific Mentalities in the Renaissance, ed. Vickers, B, Cambridge: Cambridge University Press, pp. 95-163. 